\title{
Dragon-Slayers and Jealous Rats \\ The Gendered Self in Contemporary Self-help Manuals
}

\author{
Rebecca HaZleden
}

AUSTRALIAN CATHOLIC UNIVERSITY

This article traces two broad discourses in a selection of best-selling relationship manuals from 1974 to 2004. On the one hand are manuals promoting traditional gender roles, and on the other are those promoting financial and emotional independence for women. ${ }^{1}$ In contrast to other analyses, I argue that these approaches cannot be categorised into a simplistic dichotomy of 'patriarchal' and 'feminist'. Rather, I contend, they are grounded within the fundamentally different conceptions of the nature of the self held by conservative and liberal discourses respectively-and conservative discourses are on the rise. I further argue that these ontological selves are somewhat removed from their traditional antecedents and should be understood as neo variants.

Although the term 'bestseller' is hard to define, it is likely that each book in this study at some point held the position of best-selling therapeutic relationship manual in the United States, and often also throughout the world. ${ }^{2}$ By 'therapeutic relationship manual', I mean a book grounded in popular psychology that has the putative aim of aiding the reader in developing and managing more harmonious and 
fulfilling intimate romantic relationships. This is a popular format that encompasses hundreds of new titles each year, as well as having produced some of the enduring classics of self-help - the therapeutic relationship manuals in this study are all still in print, with the exception of Marabel Morgan's The Total Woman. Books offering advice on finding a partner were excluded, as were dating, etiquette, householdmanagement and sex manuals. ${ }^{3}$ There is a certain amount of diversity between these books and I do not claim that all relationship manuals fall into the two categories used here, or that all books within a category are consistent with each other. Neither do I imply that readers simply accept and absorb the intended messages within these texts. Numerous studies have been made demonstrating that women read sceptically, interpretively and resistingly. ${ }^{4}$ Nonetheless, the unabated proliferation of self-help books and the saturation of our culture by psy truths tell us something important about our values, both on the societal level and, as self-help books are increasingly translated into numerous languages and spread across the world, at a global level as well. ${ }^{5}$ As Elias has pointed out, an advice book has to relay a message with which its audience can identify. ${ }^{6}$ In other words, the prescriptions and proscriptions within self-help are 'already constituted' realities for the readers. ${ }^{7}$

It is also important to acknowledge that women overwhelmingly constitute the readership. Relationship manuals are usually aimed at women and women are more likely to purchase and read them. ${ }^{8}$ Some self-help authors even assert that men are uninterested in self-help: 'Men don't read magazines like Psychology Today, Self, or People' because 'they are more concerned with outdoor activities, like hunting, fishing, and racing cars ... and couldn't care less about ... self-help books'. ${ }^{9}$ One author includes a small section, near the end of his book, which he encourages his readers to show to their partners and begins 'I'm assuming that this letter is the first thing you're reading in this book ... give me three minutes to talk to you man to man'.10 That the presumed audience is gendered is of crucial importance, because the 'injunction to understand one's life,' or one's self, 'for example as an autonomous individual ... can come to mean something entirely different when we look across the designations of ... gender and sexuality'.11 
-FEMINISM, SEXPERTISE AND SELF-HELP

Feminists have pointed out that some of the earliest modern experts saw women as being by nature weak, dependent and unhealthy. Femininity itself was seen as a disease-'a woman's normal state was to be sick'.12 The female mind has been pathologised from female hysteria onwards and mental illness remains gendered, at least in part because women bearing the daily burdens of gender inequality are diagnosed by medical and therapeutic experts as suffering from a personal pathology. ${ }^{13}$ Code reminds us that 'the conflation of femininity with pathology is a constant thread running through expert endeavours to control women,' and argues that feminism has largely been formed against expertise. ${ }^{14}$ This relationship, though, has been an ambivalent one, as feminism has equally embraced expertise, employed it and created it. The rise of sexpertise and popular (humanistic) psychology in particular has been entwined with feminist thought, shaping it and being shaped by it.

Self-help of the 1950s centred on household management and 1960s books focused on sex, while wider popular psychology was concerned with selfactualisation. ${ }^{15}$ Therapeutic relationship manuals per se did not come into being until the 1970s, which limits any project of tracing the shifts in self-help discourses surrounding emotional intimacy from the 1950s to the 1970s. However, one can gain some insight into the ambiguous relationship between feminism and the shifting truths of popular expertise by taking a brief look at the interrelations of discourses in sex manuals, popular psychology and influential feminist works such as Betty Friedan's The Feminine Mystique.

In the 1950s, sex manuals mostly held to the 'different and unequal' model of human sexuality, in which women's sexuality was seen as a sleeping beauty, ready to be awoken by her husband, and grounded in emotion-this being a justification of the sexual double standard. ${ }^{16}$ From its very beginnings, humanistic psychology selfconsciously opposed restrictive social norms of this kind. It emphasised the positive revolutionary power of traditionally feminine values such as spontaneity, playfulness, self-expression, intuition, supportiveness and emotional warmth. It differed from classical psychotherapies and psychoanalysis in that its aim was not so much to make the sick well, but to make the well even better: 'if there is one statement true of every living person it must be this: he [sic] hasn't achieved his full 
potential'.17 The central belief of humanistic psychology is that through psychological growth, the individual will 'develop the qualities which would cause him to value those experiences which would make for the survival and enhancement of the human race'.18 It posited the transformative and redemptive power of a therapy in which fellow human beings nurtured one another's emotions-that is, a position in which emotional labour was not just low-value women's work, but a right, and an obligation, of all human beings. Humanistic psychologies are therefore grounded in social critique. They believe in the perfectibility of human nature, regard imperfections and neuroses as arising from the damage that unduly repressive societal norms or cultures inflict on the self, and 'call for the individual's emancipation from the stifling demands of role-bound conduct'.19

For Rogers, the goal was no longer to achieve mental health but simply to be happy, to have more fun-and all this in order to make the world a better place. He gave a place of honour to the child within-arguing that that one did not have to grow up, to become a 'sensible' and self-sacrificing adult, but that one nonetheless had an obligation to change, to work on one's personality, to improve oneself. Simultaneously, rising rates of employment among women and increased acceptance of women pursuing careers outside the home contributed to a social climate that was more accepting of female economic independence. As women participated more in the labour force and began to gain formal rights to equal education and equal pay, so they sought more equality in marriage. In the 1960s and 1970 s, along with such changes as those in contraception and wider social attitudes, sexperts laid the groundwork for greater permissiveness for women's sexuality. ${ }^{20}$ To some extent, these factors began to undermine the stereotypical idea of men as productive and active with women as passive and consuming in attitudes towards sex and relationships. ${ }^{21}$

At the same time, a mass culture was forming that Lash was later to term one of 'narcissism' - in the late 1960s especially, many people explored humanistic psychology, group encounters and secular approaches to human social and personal problems, and the quest for fulfilment. ${ }^{22}$ As religion and other traditional forms of authority continued to decline, and were subject to attacks from feminism and the 'counterculture', there was a general eagerness to learn about interpersonal relations, and a new emphasis on sexual pleasure for women as well as men. 
Humanistic approaches unloosed sex from marriage and understood sexuality as a basic human quality-in this way they helped to deinstitutionalise feminine sexuality and were thus seen as broadly feminist in their implications. ${ }^{23}$

The early appeal that humanistic psychology held for feminists in the 1960s is self-evident, with its accent on questioning the norms of an oppressive masculinist society and celebrating the value of traditionally feminine traits such as emotion and intuition. However, this appeal was not unambiguous-the emphasis in Rogerian therapy on finding one's inner child and giving expression to emotions had a different resonance for women than for men, as the former were, in many ways, still treated legally and socially as children, and were often dismissed as incapable of rationality. ${ }^{24}$

Nevertheless, as other forms of expertise declined, popular psychology triumphed, and its calls for self-actualisation and self-responsibility were congruent with feminist demands. ${ }^{25}$ It is worth noting that an inextricable part of this was a campaigning social critique to raise feminist social awareness and change discriminatory legislation. For example, Friedan's The Feminine Mystique-itself often understood as a self-help book-employed many techniques of persuasion that are characteristic of relationship manuals today, such as a confessional tone and the use of 'magnified moments' or personal parables. ${ }^{26}$ But it also outlined the second-wave liberal feminist view, and was highly influential in shaping feminist thought, identifying a contradiction between mounting individualism and the traditional female role of self-effacement and self-sacrifice. Feminism thus became synonymous not only with liberal social demands for equal rights in the marketplace, but also with a demand for emotional fulfilment. Indeed, psy alliances with feminism have led some to assume 'that the history of women's emancipation is the history of their entitlement to own their feelings'. ${ }^{27}$

In the 1970s, a new feminist model of sexuality began to appear-that of individualistic sexual autonomy. Sex manuals began to focus on the private sexual experience of women: 'It is a very self-centred experience ... your focus must be solely on your sexual stimuli and whatever increases it'; 'you must assume responsibility for your own sexual pleasure'.28 This outlook saw orgasm as a right, and a product of learning, not of instinct. It was argued at the time that placing a strong emphasis on non-coital techniques rendered the man dispensable to female 
pleasure, further reinforcing women's sexual independence. ${ }^{29}$ This latter view politicises female sexual autonomy, on a model of sex among equals. ${ }^{30}$ Sex began to be understood as part of the total life experience-competence and independence in sexuality were to be attained as part of a broader, more general social pattern, and sex manuals promised that this type of sexuality would pay off in other areas of life as well. ${ }^{31}$ These sexual relations both reflected and produced more general cultural attitudes and values, stripping away the moral, sentimental and romantic notions that had surrounded female sexuality. They made respectable the unmarried sexually active woman, giving women more freedom to leave unsatisfactory partners. ${ }^{32}$ At the same time, however, women became obliged to be actively sexual beings in a way that they had not before. ${ }^{33}$ That is, women were now obliged to be free with their sexuality-competent, skilled, proficient in their own pleasure, multiorgasmic-and open to new pathologies of frigidity, emotional over-sensitivity, dependence and sexual dysfunction. These new capacities required new interventions: self-interrogation, self-examination and work upon the self. ${ }^{34}$ Indeed, the obligation to work on oneself was adopted by many feminist writers, such as Susie Orbach, for whom feminist self-improvement and self-liberation included investigating, nurturing and developing the inner self. 35

By the late 1980s, self-regard and self-liberation had become an imperative in self-help to the extent that women who did not prioritise their own self-fulfilment were characterised as psychologically disordered-'loving too much' or codependent. ${ }^{36}$ I have discussed this phenomenon elsewhere, but will mention that codependence can be characterised as a pathologisation of femininity, or as a reverse discourse with the potential to liberate women from positions of subordination. ${ }^{37}$ In this latter view, women use expertise to liberate themselves in opposition to their putative feminine nature-or at least to furnish themselves with a limited space in which they can refuse to play their appropriate gendered role. ${ }^{38}$

In her classic study of relationship manuals, Hochschild bemoans the tendency of 1980 s and 1990s' self-help to exercise a general 'paradigm of [emotional] caution'. She suggests that feminism may be 'escaping from the cage' of a social movement, to endorse and develop a capitalist ethos of private life that is foreign to its original aims and that is emotionally barren. She argues they allow 'the worst of capitalist culture to establish the cultural basis of the struggle for 
equality'. ${ }^{39}$ While Hochschild sees a paradox between what she calls the emotional 'warmth' and the 'patriarchy' of the 'traditional' books, and is surprised by the emotional 'coolness' of the approach she calls 'feminist', these are part of a long tradition of such tensions within debates about the nature and role of women-a point to which I shall return.

Next I examine texts that challenge traditional stereotypical roles for women and demonstrate that these can be seen as continuing the liberal feminist traditions. However, I argue that they are not straightforwardly feminist, and do not hold to the original values of liberal feminism. The following section discusses those books that are based around traditional, stereotypical conceptions of differences between the sexes-views that are approximately in line with the conservative vision. I argue that the conservatism in these texts has made significant concessions to neo-liberal concepts of the self.

\section{—Liberal selves AND jeALOUS RATS}

Liberal discourses traditionally posited a straightforward approach to gender roles: women should become educated, take paid work and strive for economic equality with men. Liberalism has tended to be somewhat suspicious of the irrationality of emotional connections, seeing little worth in traditional feminine values such as compassion and intuition, and not especially prizing home and family. For liberal feminists, it is in the public sphere that women should find their worth, by competing on an equal footing with men. The liberal self is active, hard-working, goal-oriented, planning for change and succeeding in shaping its own destiny. It is competitive, vigorous and energetic: it is the 'enterprising' self. ${ }^{40}$ In liberal self-help books, the reader is encouraged to carve out her own destiny, take charge of her life, seize opportunities, and develop and employ her skills and talents. Above all, she is urged to be independent, both economically and emotionally.

The books begin with warnings that 'aptly describe a woman's vulnerabilities in marriage-and what can happen when productive work is given up for the illusion of productive love'.41 Vedral, for example, states that 'the simple truth of the matter cannot be ignored: The more a woman earns, the more powerful and independent she feels, and indeed is; and the less she earns, the more at the mercy and dependent she feels, and indeed is'. ${ }^{42}$ Friedman claims: 
Work allows you more chances to grow; to stretch yourself. It enables you to meet new people, to explore challenges, even to experience the pain of rejection or initial failure. These experiences make you stronger ... Money is not the prime benefit. The prime benefit is self esteem. ${ }^{43}$

Vedral agrees that paid work should take precedence over a relationship_'if it came down to it, I would leave (and indeed have left) a man before I would leave my career'. ${ }^{4}$

One of the most crucial problems that women face, we are told, is not understanding the rules of capitalism. It is from this failure of the female mindset that many of the problems women face in the workplace spring. Friedman says:

Women tend to make moral judgments from a frame of reference that blocks their understanding of movement in the workplace. They judge workplace practices using family and friendship values, putting human needs above all. They must learn new insights about relations in the work setting ... how the system works, and why it works the way it does. It is not enough to stand aside and judge it. 45

Dowling agrees that a wish not to join the marketplace is 'phobic', and any objections to capitalism on political, humanitarian or moral grounds arise from an unhealthy personal psychology. 46

While these authors promote the involvement of women in the marketplace, they do not encourage political engagement, even on a personal level. One author warns the reader against trying to 'solve her problems by changing things on the outside' such as 'by joining a union or fighting for women's rights' because none of these external changes will untangle the confused and self-destructive attitudes lying within. 47

Financial self-sufficiency is of central importance to these texts. Norwood complains of one client that 'his mother's timely gifts of money conveniently short circuited any drive towards growth or maturity in Sean'.48 Adulthood, then, is equated with financial independence: even borrowing from a support network of female friends is seen as being shameful-as Dowling says of a group of female friends she spent time with after her divorce:

we were ... hiding. We seemed to be more interested in maintaining our lives exactly as they had been ... than in rising to the challenge of making 
something new ... I didn't want to be alone, to experience myself as being alone, so I continued to share my responsibilities as I had always done. None of us really wanted to make decisions on our own. We consulted all the time-particularly on things having to do with the kids. We lent money to one another ... We were shameless in the expression of the weakness that we felt within. 49

Similarly, the support of family is suspect. Friedman quotes the 'Wise words. Wonderful words' of a client who says that:

Nobody is going to save you; that's your job. Save yourself. If you don't like where you are, get out of there. The object is not for them to like you, the object is for them to listen to you ... Your family thinks of you as a pet, you have to leave them. They are just where you came from, they are not what you are. 50

Friedman suggests that one of the most important things a woman can develop is the kind of 'personal power' that 'endows you with a sense of worth ... a sense that people respect you-which, on occasion may be more important than the knowledge that they love you'. She encourages her reader to develop 'NO! power'that is, 'mastering the word NO'. 'Ideally,' says Friedman, 'we can love and let be. But we can also love and let go if it's necessary.'51

In order to encourage their readers to disengage from romantic relationships and involve themselves in establishing financial independence, some of the authors go to some lengths to outline the various ways in which men can be lacking or defective.52 In these and other relationship manuals, readers are encouraged to classify men as gloomy, smothering and jealous, passive-aggressive 'rats', alcoholics, workaholics, sexaholics or sociopaths, sapping the strength and energy of their female partners. Indeed, many of these texts present love itself as an addiction, disease or pathology. 53

For these authors, gender differences take the form of women's economic dependence and men's psychological defectiveness. Restrictive gender roles can be overcome, they say, on an individualised basis, by entering the job market in order to earn a wage independently of one's partner, by being wary of men in general on the grounds that they are likely to be dangerous or damaged and, when in a relationship, by detaching oneself from moral or ethical obligations towards a 
partner such as to be sexually and emotionally faithful, or to honour a commitment to stay with him. ${ }^{54}$ It is vital, therefore, that women begin to take responsibility for themselves, because it is 'when we assume responsibility for our own problems that the center of gravity begins to make that crucial shift from the Other to the Self'.55

The liberal flavour of these books is clear: it is the realm of paid work, commerce and enterprise in which women should find personal fulfilment, for it is here they will find independence from men. Independence is the basis for psychological health, adulthood and fulfilment; self-reliance and self-responsibility are the foundations of the teleological liberal self. This 'enterprising' self is one that concentrates on economic productivity and displays initiative, enterprise and selfresponsibility. ${ }^{56}$ It is active, vigorous, takes measured and calculated risks, welcomes change and produces wealth. It plans and tactically executes strategies, shaping itself and its own individual destiny. It shows faith in, and relies upon, its own talents and abilities. It is robust, competitive and self-evaluating. Much emphasis is laid on what should emanate, or derive, from the individual: self motivation, personal drive, personal vitality, self-assertion, self-reliance and the self-made individual.57 This view of the self asserts that one should take responsibility for one's own happiness, and that one has an obligation to exercise one's abilities or talents in order to help oneself. These books encourage change and risk, and prize economic autonomy above all. They promote strategies, plans and tactics, and reliance on one's own talents. Sharing doubts, responsibilities or finances with others is condemned as symptomatic of weakness, a failure of self-sufficiency-a failure of self.

It is worth pausing here to consider that, historically, the liberal approach advocated women's complete engagement with, and immersion in, the public spheres of work and politics. A fulfilling life was understood to be a nurturing life, committed to family and community responsibility, empathy for others, cooperation, and the maintenance of social ties. ${ }^{58}$ The books in this study do not quite take this view, and perhaps are better understood as taking a neoliberal position. For, while they continue to promote the involvement and achievement of women at work, this does not extend to the realms of campaigning politics or community responsibility. That is to say, the books reveal no notion of engaging in the fight for equal opportunities, demands for an end to the glass ceiling, better childcare 
facilities, or other aspects of the program of explicitly social change that were once central to the liberal view. Indeed, any recourse to, for example, women's support groups, is seen as false thinking and a failure of the individual will. Furthermore, rather than rejecting the notion of a vast disparity between the sexes, and holding a fundamental respect for both men and women, as found in traditional liberal arguments, the neoliberals in these books seem to border on positing fundamental differences between the sexes-but they portray men as needy, childish, jealous and dependent, and women as capable, independent and adult.

Similarly, these books emphasise liberalism's focus on the market to the point that they are best understood as having a neoliberal conception of the self. The marketplace is embraced to the point that they may suggest that women who are critical of the economic system have a psychological disorder. The social tolerance and respect for difference of historical liberalism is replaced with an 'anything goes' free market ethos, and the respect for difference and the nurturing ideology found in traditional liberalism is replaced by a contempt for those who cannot live up to this ideal self-whether collectivised women or needy and dependent men. Indeed, this kind of ideal neoliberal self often defines itself apophatically-it is not weak, collectivist or dependent. It regards the self that is bound up with others as committing the moral error of abdicating individual responsibility and initiative. 59

\section{-CONSERVATIVE SELVES AND DRAGON SLAYERS}

Traditional conservative discourses, on the other hand, have long held women to be different and special. They consider 'womanly' virtues such as intuition, compassion and love, and the feminine sphere of the family and home, to be essential antitheses to the inhumane world of the marketplace. They also value feminine self-effacement and submission, and therefore the worth attached to these virtues is ambiguous, implying a certain inferiority, and carrying an expectation of female obedience.

The conservative view of the ideal self is rooted in long-established tradition and continuity. The conservative self values time-honoured virtues such as hard work, patriotism and religion, and most especially Biblical moral codes. It places its faith in these and in the accumulated wisdom of habit, convention and custom. It believes in duty, a 'natural' social order and a correct, normal way of life. Morality is whole and wholesome, but subject to degenerate social practices that may erode, 
decay or rupture it.60 Conservatism is therefore opposed to social change and permissiveness, and it esteems traditional family life, 'the very bearer of conservative values' ${ }^{61}$ Thus conservatism traditionally carries with it an ambiguity towards capitalism's emphasis on progress and self-gratification.

For conservatives, God has moral authority over humans, adults have moral authority over children and men have moral authority over women. ${ }^{62}$ Concepts of gender differences are central to the traditional, or as Hochschild would have it, 'patriarchal', self-help books, and many begin with explanations of them. ${ }^{63}$ They may do this through religious dogma-for example: 'God ordained man to be the head of the family, its president, and his wife to be the executive vice-president'; and 'God didn't design us to be the same; he designed us to be different'. ${ }^{64}$ Schlessinger says that wives must 'submit to the will of her husband because the will of her husband will be obedience to the Lord'.65 Other explanations make vague allusions to 'nature': 'Trying to deny how my gender affects my nature brought out the worst in me and put a huge strain on my marriage' says Doyle, and McGraw warns us of 'the price you pay for resisting the natural order of things'.66 This 'natural order' may be posited by alluding to sociobiology, such as DeAngelis's description of a man who 'must go out and hunt, and he must not come back until he has killed ... He must be strong ... He is a man. He is a hunter', and McGraw's assertion that there is no need for a woman to 'muscle up and defend the cave'.67

Whatever the explanations for gender differences, these books tend to recycle clichés about passive, emotional women and active, logical men. As one observer has suggested, they posit that 'subjects are from Mars and objects are from Venus'.68 McGraw says, for example, that 'Men criticize women because they are emotional, sensitive, and intuitive rather than one-dimensionally logical ... God gave men less of those qualities and more of certain other qualities such as logic and physical strength'.69 Gray claims that women 'value love, communication, beauty, and relationships ... They experience fulfilment through sharing and relating ... They enjoy wearing a different outfit every day ... They may even change outfits several times a day as their mood changes.' Men, however, 'value power, competency, efficiency, and achievement. They are always doing things to prove themselves and develop their power and skills ... They experience fulfilment primarily through success and accomplishment.'70 While women place a higher value on their 
relationships than on their careers, for a man, 'work has a bigger influence on his sense of self-worth than his relationship with you does'. ${ }^{71}$

Schlessinger in particular is insistent that most of the problems in marriages are because women are 'ungrateful', 'selfish', 'cruel and abusive' and too 'complicated'.72 In contrast, men are 'just not that complicated', 'simple, straight-line types', and 'loyal as dogs'. ${ }^{73}$ Women are 'mysterious', 'manipulative', 'mercurial', 'hypersensitive', 'whiners', 'complainers' and 'nags'. Indeed, 'nagging is part of the female XX chromosomal information ... simply built into the DNA'.74

These books are based almost entirely on the idea that men and women are vastly different; DeAngelis says that men and women are so foreign to each other, that men 'can't understand a word you're saying'. ${ }^{75}$ Similarly, Gray insists that men and women are alien to each other, advising his readers to 'remember that your partner is as different from you as someone from another planet'. ${ }^{76}$ McGraw agrees that men and women are fundamentally incompatible:

You and your partner are programmed for conflict. The fact that you are involved with a member of the opposite sex-and I emphasize the word opposite-means that you are trying to mesh your life with someone who is physically, mentally, emotionally, and socially different than you. ${ }^{77}$

For these authors, most problems in personal relationships, and indeed in society, arise because gender roles are becoming blurred: 'The problem is, the more we attempt to blur roles into a unisex world, the more we are spinning out of control and try to fix 'what isn't broke'78- and what isn't broke is the view that women are not really interested in, or suited to, work outside the home. Schlessinger states that 'The more we ignore the true, inherent masculine and feminine qualities of people, the farther apart we pull them ... women who have reversed societal roles ... seem to have less regard for their husbands ... and suffer ferocious guilt' over the children. ${ }^{79}$ She insists that the consequences of women having careers include the 'neglect of children', and for the woman herself, 'weight gain, low sex drive, moodiness, and fatigue' leaving her 'feeling hostile and depressed'. ${ }^{80}$ Since Doyle 'surrendered', she and her husband have had a division of labour based on 'the strengths each of us brings because of our respective genders. For instance, while I was stressed out and resentful about making most of the money at a corporate job, John is happy and proud to be the primary breadwinner' and insists that 'the two roles are 
complimentary $[$ sic]'.81 Similarly, Gray claims that 'many men have denied their masculine attributes in order to become more nurturing and loving. Likewise many women have denied some of their feminine attributes in order to earn a living.' 82 Schlessinger describes women with careers as 'worker-ants', in contrast to the male worker who 'slays dragons every day'. Women feel 'drained' by work, she says, because at work you are not 'loved, adored and intimately needed'. She goes on to advise readers to 'check out all the competitive backbiting, layoffs, and computerization and mechanization substitutions for human beings going on in the workplace'.83

It is this sort of statement in conservative manuals that led Hochschild to assert that such 'patriarchal' books are non-commercial and 'warm'. However, it is worth noting that Gray devotes a section of his book to the ways in which men and women can 'score points' with each other, and he goes into some details about the different ways in which men and women add up these scores. ${ }^{84}$ Similarly, McGraw discusses the importance of what he calls 'pay-offs', and in several places Morgan, Doyle and Schlessinger all assess the extent of their partners' love by the gifts they are given. 85

In addition, it is often difficult to discern much warmth in the advice from Doyle to 'hold your tongue' and 'be quiet' because 'talking about feelings is not a popular pastime in the male culture ... so be polite', and most importantly 'never ask a man how he feels'. She insists we should forget the notion that 'more communication is the key to an intimate marriage'.86 Schlessinger insists that it doesn't matter if a woman does not understand her husband's meaning as long as 'she looks as interested as she can even when she doesn't follow or understand what he's talking about'. 87 She quotes a satisfied client as saying, 'Things have been so much happier in our home and our marriage since I started taking my problems to God instead of my husband" and advises all her readers to 'cut down on communication' because a husband is not 'a listening board, girlfriend or shrink'.88 Gray claims that 'When a woman in a caring and concerned way says to a man "What's the matter, honey?" he may feel insulted or repulsed' 89

As well as proscribing expressions of concern towards a male partner, Gray insists that no matter what the circumstances, the female partner 'should definitely not offer ... advice'. ${ }^{90}$ To illustrate, Gray relates a story in the style of a fairytale. It 
begins when a knight rescues a princess from a dragon, and the pair subsequently fall in love and begin to live together, but the princess makes the mistake of helping the knight by giving him a noose and some poison to use against dragons. Later, the knight hears cries from a different damsel in distress, and comes to her aid:

But as he draws his sword to slay the dragon, he ... hesitates. He wonders, Should I use my sword, the noose or the poison? What would the princess say? For a moment he is confused. But then he remembers how he had felt before he knew the princess, back in the days when he only carried a sword. With a burst of renewed confidence he throws off the noose and poison and charges the dragon with his trusted sword. He slays the dragon and the townspeople rejoice. The knight in shining armor never returned to his princess. He stayed in this new village and lived happily ever after. He eventually married, but only after making sure his new partner knew nothing about nooses and poisons. ${ }^{91}$

Gray's views on gender have been described as 'archaic bromide' 92 and while this particular fairytale may seem ludicrous, it found its way into the literature of federally funded school education programs in the USA. ${ }^{33}$ Schlessinger refers to men throughout her book as 'dragon-slayers', assuming her readers' familiarity with Gray's book and this particular fable. Gray's views are unexceptional in conservative self-help literature. In 1973, Morgan warns her reader, 'Don't give him advice ... He needs your ear, not your mouth.' Nearly thirty years later, Doyle insists that 'we all like to be asked our opinion, you need to resist giving it'. 94

If a man is troubled, his partner should 'focus on taking care of yourself' and 'do something that makes you happy ... read a book, listen to music, exercise, listen to self-improvement tapes, take a bubble bath, see a therapist, [or] go shopping'. 95 Doyle declares that she prefers to 'keep all my energy for improving my happiness ... and to look inward instead of outward', and Schlessinger insists that rather than worrying about her partner's happiness, a woman 'has to learn how to take care of her own emotions better'. ${ }^{96}$ Instead of focusing attention on the relationship with her partner, the reader is encouraged to develop a relationship with the self, involving examining, loving and nurturing the self while detaching from others. ${ }^{97}$

For Doyle, the reader is to continue to surrender, no matter what the consequences: 'He may lose money. He may make you late. He may make a mess, or 
lose his job or let the bills go so long that the water gets turned off.' The only situation in which a woman is entitled to defy her husband is if he requests her to do something that would require her to 'sacrifice your emotional or physical wellbeing' and in this case then 'you must simply say, "I can't"'.98

In this we can see that although Doyle advocates deferring to one's husband in matters concerning the well-being of one's family and children, she allows, and later insists, that the reader should always give priority to taking care of herself. If a man asks for some help with a task that should rightly be his, the reader must refuse. Of one woman who refuses to help her husband by going to pay the bills, Doyle says 'While her instinct was to be helpful, she also felt a surge of pride pulse through her when she stayed true to her commitment to herself not to take on the burden of handling the finances instead of rescuing him.' 99 Thus the surrendered wife must assert herself in order to submit to her husband.

DeAngelis relates a story illustrating the same point. She was in a car being driven by her male partner, and she noticed that he failed to turn off at the correct exit from the motorway. She did not tell him this because for her it is vital, no matter what the situation, to let her partner make his own mistakes and 'live with the consequences'. If he objects, the advice is to 'sympathize with his frustration, and go about your own business'.100

In addition to the scenarios above in which a woman must surrender to the point at which she is living in a home with no water and her husband has lost his job, she must also do so when 'the kids get bruised knees'.101 Schlessinger argues that many women 'tend to get very self-centred when they have children. They begin to think that their babies are the centre of the universe.' Elsewhere she admonishes a caller to her radio show for protecting her daughter against her husband's anger, saying this is 'because the first and foremost relationship in that house is between you and your husband'; she recommends prioritising the husband-wife relationship over the mother-child relationship. ${ }^{102}$ Leaving aside the assertion that caring for a baby is a self-centred activity, it is noteworthy that the 'family values' espoused by these conservative women include putting children at risk in order to submit to the husband.

Although all the books hold teleological concepts about society, Schlessinger's book is unusual in that she specifically states that her book is not only 
concerned with intimate relationships, but has a wider social significance. She repeatedly condemns 'feminist gobbledegook' as a 'grandiose self-centredness about the value of women' and blames women's economic independence for growing selfishness and the collapse of social order. She identifies 'an assault upon, and virtual collapse of, the values of religious morality, modesty, fidelity, chastity, respect for life, and commitment to family and child-rearing' - and claims this assault is at the root of all society's ills. Significantly, she allies conservative values and traditional domestic relationships with wider discourses of nationhood and patriotism, claiming that the 'denigration of traditional masculine values ... undermines the home and country'.103

-THE NEO SELF

For conservatives, the world is a dangerous place in which the moral order is always under threat from social change. It is only God's will, expressed through the husband's central authority over, and protection of, his wife and children, that can keep the family safe from harmful external influences. ${ }^{104}$ The conservative books in this study take just such a view of gender roles. They state that there are vast, fundamental differences between the sexes, and posit explanations for these such as evolution and/or divine order. They cast as 'revelations' the romantic gender stereotypes of the passive, emotional female and contrast these with the active, logical male, thereby implying or stating that these differences make women unsuited to (aspects of) the capitalist system of paid work. Independence for women is seen as eroding men's responsibilities, leading to resentment on both sides, and to men feeling emasculated. They therefore prescribe a traditional role to the woman of submitting to her husband on matters of finance, sex, childrearing, and so on. They share with conservatism a view of the ideal self as rooted in, and continuous with, tradition, history, and divine order. They assert a 'natural' and hierarchical moral order, and place their faith in traditional family values and gender roles. ${ }^{105}$

But conservatism has traditionally held ambivalent views towards capitalism, deploring the fast pace of change and self-gratification of the marketplace, the loss of traditional communities, civic duty and time-honoured moral values. Early conservatives saw public life as brutal, heartless and inhumane, and held women-albeit ambivalently—to be morally above the market. Women 
were ethically superior, virtuous, humane and compassionate. These books might therefore be better understood as comprising a particular type of neo-conservatism, with an emphasis on traditional social roles, such as gender roles, but without the ambivalence towards rapid economic changes or the implied critique of the capitalist economic order, industrialism and the consumer society that was once implicit in this approach. Their argument seems to be that women are naturally unsuited to the world of work and money, and that they should therefore withdraw from it, but there is no notion that these naturally emotional women could, or should, offer any criticism of the amoral nature of the market and the adiaphoric human relations therein. Furthermore, while nineteenth-century conservatism saw the home as a haven from the marketplace, indeed as its antithesis, Morgan, Schlessinger and Doyle evaluate their partners' love by the quality of their gifts, and Gray's 'points' and McGraw's 'pay-offs' constitute an incursion into the family of market rules of calculation. The sacrosanct role of motherhood is also undermined in these books, as the central relationship of husband and wife is to be prioritised to the extent of putting the children in harm's way.

\section{-CONCLUSION}

The books in this study form a snapshot of changing social attitudes to gender and the self over a period of thirty years. Although they are all written by American authors, they were all also best-sellers in Australia, Britain, and other markets around the world, and therefore provide a picture of widespread changes in political and social values. Without wishing to make false claims regarding the influence of popular psychology, it is clear that there is at least some correlation between the types of self-help book produced and the values of its era. For as long as self-help books are used in government programs in such areas as education or health, the very 'private' area of intimate life and the relationship of the self will be one way in which we 'enfold' authority and political ideologies into our private self-understanding. ${ }^{106}$

The period of time over which these texts were published has been one of great transformations for women, society and politics-beginning with the remains of the counterculture, collectivist politics and second-wave feminism in the 1970s, through the rise of neoliberalism in the 1980s and early 1990s, to the reinvention of the Left, making significant concessions to the Right, and especially to neoliberalism. 
The contents of the relationship manuals in this study form part of this history, with Morgan in the early 1970s defending traditional gender roles, books in the 1980s and early 1990s revealing a strongly neoliberal approach, and those from the beginning of this century promoting 'family values' and increasing biological determinism.

However, what is perhaps most striking is not the points on which the liberal and conservative books differ, but those on which they agree. The books containing (neo)conservative views of the role of women and those (neo)liberal ones that stipulate female independence and equality both prescribe an emotional aloofness from one's partner and advocate the individualised telos of concentration on oneself. Indeed, what is most striking about the two groups is that they both use their own views on gender to justify and promote this ethic. The neoliberal view sees emotional attachments, in particular men's emotional immaturity, as holding women back from achieving personal fulfilment, which is properly achieved through their careers. The neoconservative view claims that emotional closeness is a feminine value, and instructs women to respect men by disengaging from them. The two traditions discussed here make different assumptions about the nature and role of women, assuming, permitting and requiring different types of self in both men and women-but neither is based in intimacy or commonality, and both prescribe detachment.

Furthermore, neither approach can legitimately claim to be feminist, as neither supports social or political action to further women's advancement. Rather than understanding these two types of discourse in self-help books, as 'feminist' or 'sexist/patriarchal', I propose that they are best understood as continuing the long debate between (neo)liberal and (neo)conservative conceptions of the ideal self. Such conceptions of the self posited in humanist psychologies and popular psychology books are of no small significance to the ways in which people understand themselves. Contemporary individuals are incited to live as if making themselves a project-they must work on their selfhood, the kind of person they are, the relationships they have with others and with themselves, their relation to work and employment, and so on, in order to develop a style of living. ${ }^{107}$ These identity projects are linked with the rise of the 'engineers of the human soul'-of which self-help books are but one example. ${ }^{108}$ This may seem to be a private and 
intimate area, but has increasingly become the object of political attention, intertwined with notions of the good life, the active citizen and the right thing to do-and nowhere is this more apparent than in discussions of appropriate gender roles. The use in public education of Gray's story about the henpecked dragon-slayer is one example of the areas in which 'private' self-understanding can be shaped by 'public' political discourses to promote a 'right way' of life. This is central to the ways in which the authorities of governance understand individuals; the mature, responsible adult on a linear journey of growth and self-improvement is essential to the values of the enterprise culture. The contemporary self is a self that must be sought out, realised and achieved, and which unites psy and enterprise values. ${ }^{109}$ That is to say that the self understood through humanistic psychology is 'congruent with the political rhetoric of enterprise.'110 Values such as self-esteem and selfassertion were central to second-wave feminism, while simultaneously potentially undermining some of its social critique and transformative power. If success is a matter of self-esteem then it follows that the only thing holding women back is a negative mindset: 'women don't think of themselves as equal to men so they don't act equal; consequently men, employers, relatives, society, do not treat them as equal'.111

Since the turn of the century, the most prevalent 'right way' of life reflected and promoted in self-help books has turned away from the liberal view, towards a new type of gender conservatism, placing an emphasis on obedience to male and religious authority, the importance of family, and so on, in which conservative notions of civic responsibility seem to have disappeared, and been replaced with a newfound faith in a kind of individual free-for-all of self-concern and self-love. Far from being emotionally 'warm', this ethic advocates tradition without community, partnership without intimacy, and (for women) a withdrawal from the world of paid work and financial concerns, without entertaining any notion of social critique.

Rebecca Hazleden's research interests centre around self and identity, gender and sexuality, intimacy and popular culture. She has taught at universities in Britain, 
New Zealand and Australia, and is currently teaching at the Australian Catholic University.

\begin{abstract}
-NOTES
1 Those promoting traditional roles are: Marabel Morgan, The Total Woman, Harper Collins, London, 1973; Barbara DeAngelis, Secrets About Men Every Woman Should Know, Thirsons, London, 1990; John Gray, Men are From Mars, Women are From Venus, Harper Collins, London, 1993; Laura Doyle, The Surrendered Wife, Simon and Schuster, London, 2000; Phil McGraw, Relationship Rescue: Don't Make Excuses! Start Repairing Your Relationship Today, Vermilion, London, 2001; Laura Schlessinger, The Proper Care And Feeding of Husbands, Harper Collins, New York, 2004. Those promoting independence for women are: Joyce Vedral, Get Rid of Him!, Warner Books, New York, 1994; Charlotte Dowling, The Cinderella Complex, Summit Books, New York, 1981; Susan Friedman, Smart Cookies Don't Crumble, GP Putnam's Sons, New York, 1985; Robin Norwood, Women Who Love Too Much: When You Keep Wishing and Hoping He'll Change, Pocket Books, New York, 1986; Susan Forward, Men Who Hate Women and the Women Who Love Them, Bantam, New York, 1986.
\end{abstract}

${ }^{2}$ See note 3 , below.

${ }^{3}$ For further details on the methodology, including selection of texts and available sales figures, see Rebecca Hazleden, 'The Pathology of Love in Contemporary Relationship Manuals', Sociological Review, vol. 52, no. 2, May 2004, and Rebecca Hazleden, 'The Relationship of the Self with Itself in Contemporary Relationship Manuals', The Journal of Sociology, vol. 39, no. 4, December 2003. All the books in this study originated in the USA, as these are the ones that tend to become global bestsellers. For more on the US-nature of the most successful self-help books, see Hazleden, 'Relationship of the Self with Itself'.

${ }^{4}$ Wendy Simonds, Women and Self-Help Culture: Reading Between the Lines, Rutgers University Press, New Jersey, 1992; Janice Radway, Reading the Romance, London, Verso, 1984; Lisa Rosenblatt, Literature as Exploration, fifth edition, MLA, New York, 1995; Judith Fetterley, The Resisting Reader: A Feminist Approach to American Fiction, Indiana UP, Bloomington, 1978; Yvonne Rowe, 'Beyond the Vulnerable Self: The 'Resisting Reader' of Marriage Manuals for Heterosexual Women' in Rhizomes: ReVisioning Boundaries, SLCCS, University of Queensland conference papers February 2006 pp. 24-5. ${ }^{5}$ Nikolas Rose, Inventing Our Selves: Psychology, Power and Personhood, Cambridge University Press, Cambridge, 1998.

${ }^{6}$ Norbert Elias, The Civilising Process, vol. 1: The History of Manners, Blackwell, Oxford, 1978, pp 68-9. ${ }^{7}$ Lisa Blackman, 'Self-help, Media Cultures and the Production of Female Psychopathology', European Journal of Cultural Studies, vol. 7, no. 2, 2004. 
${ }^{8}$ Arlie Russell Hochschild, 'The Commercial Spirit of Intimate Life and the Abduction of Feminism: Signs From Women's Advice Books' in Theory, Culture and Society, vol. 11, no. 2, 1994. Lisa Wood, 'The Gallup Survey: Self-Help Buying Trends', Publishers Weekly, vol. 234, no. 33, 1988, p. 33. Steven Starker, Oracle at the Supermarket: The American Preoccupation With Self-Help Books, Transaction, Oxford, 1998, p. 152. Simonds, pp. 23, 33.

${ }^{9}$ Gray, p. 16.

10 McGraw, p. 252.

11 Blackman, p. 220.

12 Barbara Ehrenreich and Deidre English, For Her Own Good: 150 Years of the Experts' Advice to Women, Pluto, London, 1988, p. 110.

${ }^{13}$ See, for example: Michel Foucault, The History of Sexuality, vol. 1, trans. R. Hurley, Penguin, Harmondsworth, 1978; Ehrenreich and English passim; Caroll Smith-Rosenberg, 'The Hysterical Woman: Sex Roles and Role Conflict in Nineteenth-century America', Social Research, vol. 39, no.4, 1972, pp. 652-78; Elizabeth Showalter, The Female Malady: Women, Madness and English Culture, Penguin, New York, 1987. Lynn Jamieson, 'Intimacy Transformed?', Sociology, vol. 33, no. 4, 1999; Jill Matthews, Good and Mad Women: The Historical Construction of Femininity in the 20th Century, Allen and Unwin, Sydney, 1984.

${ }^{14}$ Lorraine Code, What Can She Know? Feminist Theory and the Construction of Knowledge, Cornell University Press, Ithaca, 1991, p. 208.

15 F.M. Cancian and S.L. Gordon, 'Changing Emotion Norms in Marriage: Love and Anger in US Women's Magazines Since 1900', Gender and Society, vol. 2, no. 3, 1998, pp. 308-42; Eva Moskovitz, '“It's Good to Blow Your Top": Women's Magazines and a Discourse of Discontent 1945-1965', Journal of Women's History, vol. 8, no. 3, 1996, pp. 66-98; Simonds, p. 234-7.

${ }^{16}$ Martin S. Weinberg, Rochelle Ganz Swensson and Sue Kiefer Hammersmith, 'Sexual Autonomy and the Status of Women: Models of Female Sexuality in US Sex Manuals from 1950-1980', Social Problems, no. 30,1983 , pp. $312-24,316$.

17 William C. Schutz, Joy: Expanding Human Awareness, Grove Press, New York, 1967.

18 Carl Rogers, On Becoming a Person, Houghton Mifflin, Boston, 1961, pp. 12, 20 (emphasis added).

19 John Steadman Rice, A Disease of One's Own: Psychotherapy, Addiction, and the Emergence of Codependency, Transaction Publishers, New Jersey, 1992, p. 340.

20 William Howell Masters and Virginia Eshelman Johnson, Human Sexual Response, Little, Brown, Boston, 1966. K. Mason, J. Czajka and S. Arber, 'Changes in US Women's Sex-Role Attitudes 1964-1974', American Sociological Review, no. 41, 1976, pp. 573-96.

${ }^{21}$ Weinberg, Swensson and Hammersmith.

22 Christopher Lasch, The Culture of Narcissism: American Life in an Age of Diminishing Expectations, Norton, New York, 1979. 
${ }^{23}$ Weinberg, Swensson and Hammersmith, p. 316.

24 One client of Rogers complained she felt 'coddled' by him as he didn't allow much scope for her 'spitfire self', in J.D. Andrews, 'Integrating Visions of Reality: Interpersonal Diagnosis and the Existential Vision', American Psychologist, vol. 44, no. 5, 1989, p. 805.

25 Philip Rieff, The Triumph of the Therapeutic: Uses of Faith After Freud, second edition, University of Chicago Press, Chicago, 1987.

26 Betty Friedan, The Feminine Mystique, Norton, New York, 1963. On techniques of persuasion, see Rebecca Hazleden, “'You Have to Learn these Lessons Sometime”: Claims to Authority and Techniques of Persuasion in Bestselling Relationship Manuals', Continuum, vol. 24, no. 2, 2010, pp. 291-305. For 'magnified moments', cf Hochschild.

${ }^{27}$ Pinch, p. 101.

28 P. Newhorn, Primal Sensuality: New Horizons and Explorations for Lovers, GP Putnam, New York, 1973, pp. 212, 211

${ }^{29}$ Anne Koedt, 'The Myth of the Vaginal Orgasm', in Anne Koedt, Ellen Levine and Anita Rapone (eds), Radical Feminism, Quadrangle Books, New York, 1975. S. Lydon, 'The Politics of the Orgasm', in Robin Morgan (ed.), Sisterhood is Powerful: An Anthology of Writings from the Women's Liberation Movement, Random, New York, 1970.

30 cf Kate Millet, Sexual Politics, Avon, New York, 1969.

${ }^{31}$ Weinberg, Swensson and Hammersmith p. 319.

${ }^{32}$ Weinberg, Swensson and Hammersmith p. 320.

33 K. Bauman and R. Wilson, 'Sexual Behavior of Unmarried University Students in 1968 and 1972', Journal of Sex Research, no. 10, 1974, pp. 327-33. M. Zelnick and J. Kantner, 'Sexual and Contraceptive Experiences of Young Unmarried Women in the United States, 1976 and 1971', Family Planning Perspectives, vol. 9, no. 2, 1977, pp. 55-71.

${ }^{34}$ Hazleden, 'Relationship of the Self with Itself'.

${ }^{35}$ Susie Orbach, Fat is a Feminist Issue, Paddington Press, London, 1978.

36 cf Norward.

37 Hazleden, 'Pathology of Love'. cf J. Krestan and C. Bepko, 'Codependency: The Social Reconstruction of the Female Experience', Smith College Studies in Social Work, no. 60, 1990, 216-32; Karen Van Wormer, 'Codependency: Implications for Women and Therapy', Women and Therapy, vol. 8, no. 4, 1990, pp. 51-63.

38 See, for example, Anthony Giddens, The Transformation of Intimacy: Sexuality, Love and Eroticism in Modern Societies, Polity, Oxford, 1992 and Leslie J. Irvine, 'Codependency and Recovery: Gender, Self and Emotions in Popular Self-Help', Symbolic Interaction, vol. 18, no. 2, 1995, pp. 145-63.

${ }^{39}$ Hochschild, pp. 4, 2, 11-12. 
$40 \mathrm{cf}$ Paul Heelas, 'Reforming the Self: Enterprise and the Characters of Thatcherism' in Russell Keat and Nicholas Abercrombie (eds), Enterprise Culture, Routledge, London, 1991, p. 74.

${ }^{41}$ Friedman, p. 220. Further discussion about the illusory and dangerous nature of love can be found in Hazleden, 'Pathology of Love'.

42 Vedral, p. 51.

${ }^{43}$ Friedman, p. 229. Note that the possibility of prolonged or consistent failure does not feature in these texts.

44 Vedral, p. 55.

${ }^{45}$ Friedman, p. 232.

${ }^{46}$ Dowling, p. 86, 57.

${ }^{47}$ Dowling, p. 64.

${ }^{48}$ Norwood, p. 74-5 (emphasis added).

49 Dowling, p. 35.

${ }^{50}$ Friedman, p. 216.

${ }^{51}$ Friedman, pp. 125, 246, 176.

52 Hazleden, 'Pathology of Love'.

53 Vedral, p. 96-7, 82; Norward, p. 121; Beattie, p. 148; Forward, p. 67. Hazleden, 'Pathology of Love'.

${ }^{54}$ Hazleden, 'Relationship of the Self with Itself'.

55 Dowling, p. 226.

${ }^{56}$ Heelas, p. 74.

${ }^{57}$ Heelas.

${ }^{58}$ George Lakoff, Moral Politics: How Liberals and Conservatives Think, second edition, University of Chicago Press, Chicago and London, 2002, pp. 109-10.

${ }^{59}$ Heelas, p. 74. Nikolas Rose, 'Governing the Enterprising Self' in Paul Heelas and Paul Morris (eds), The Values of the Enterprise Culture: The Moral Debate, Routledge, London, 1992.

${ }^{60}$ Lakoff, pp. 90-1.

${ }^{61}$ Heelas.

${ }^{62}$ Lakoff, p. 105.

${ }^{63}$ Hochschild.

${ }^{64}$ Morgan, p. 70; McGraw, p. 221.

${ }^{65}$ Schlessinger, p. 150.

${ }^{66}$ Doyle, p. 161; McGraw, p. 222.

67 DeAngelis, p. 7-8; McGraw, p. 42. 
68 Brenda Cowlishaw, 'Subjects are from Mars, Objects are from Venus: Construction of the Self in Selfhelp', Journal of Popular Culture, vol. 35, no. 1, 2001, pp. 169-84.

${ }^{69}$ McGraw, p. 221.

${ }^{70}$ Gray, p. 18, 16.

${ }^{71}$ DeAngelis, p. 121.

${ }^{72}$ Schlessinger, p. 115, 1, 88, 92.

${ }^{73}$ Schlessinger, p. 121, 110, 44, 117.

74 Schlessinger, p. 149, 37-65, 148, xx, passim 37-65, 43.

${ }^{75}$ DeAngelis, p. 219.

${ }^{76}$ Gray, p. 5.

${ }^{77}$ McGraw, p. 211.

${ }^{78}$ McGraw, p. 42.

${ }^{79}$ Schlessinger, p. 153.

${ }^{80}$ Schlessinger, p. 21.

${ }^{81}$ Doyle, pp. 157, 186. DeAngelis and Schlessinger also both insist that the male partner should be the primary breadwinner. One wonders about the consequences for their marriages of the financial success of their books.

82 Gray, p. 7.

83 Schlessinger, p. 25, passim.

${ }^{84}$ Gray, pp. 180-207.

${ }^{85}$ Gray,pp. 65, 97, 101; Morgan, pp. 26, 68, 109-19; Schlessinger, pp. 63, 162.

${ }^{86}$ Doyle, p. 67.

${ }^{87}$ Schlesinger, p. 41.

${ }^{88}$ Schlessinger, pp. 96, 155.

${ }^{89}$ Gray, p. 82.

90 Gray, p. 79.

91 Gray, pp. 139-40.

92 P. Horn in Karen S. Falling Buzzard, 'The Coca-Cola of Self-Help', Journal of Popular Culture, vol. 35, no. 4, 2002, pp. 89-102, 91.

93 Henry Waxman, The Content of Federally-Funded Abstinence-Only Education Programs, United States House Of Representatives Committee On Government Reform: Minority Staff Special Investigations Division, 2004, p. 51. Although Waxman does not seem to be familiar with Gray's work, the fable used in the educational material is almost identical.

94 Schlessinger passim; Morgan, p. 136, Doyle, p. 127.

95 Doyle, p103, Gray, p77. 
${ }^{96}$ Doyle, p. 25; Schlessinger, p. 97.

${ }^{97}$ Hazleden, 'Relationship of the Self with Itself'.

98 Doyle, pp. 53, 55-6.

${ }^{99}$ Doyle, p. 168.

100 DeAngelis, pp. 34, 32.

${ }^{101}$ Doyle, p. 53.

102 Schlessinger, pp. 29, 86-7, 98-9.

103 Schlessinger, pp. 91, 54, passim, pp. 53, 6 (emphasis added).

104 cf Lakoff, p. 67.

105 cf Lakoff, p. 105

106 Waxman; Neil Frude, 'A Book Prescription Scheme in Primary Care', Clinical Psychology, vol. 11, no. 4, 2004, pp. 30-3; Paul Farrand, 'Development of a Supported self-help Book Prescription Scheme in Primary Care', Primary Care Mental Health, no. 3, 2005, pp. 61-6; Scott Cheery, 'The Ontology of a Selfhelp Book: A Paradox of its Own Existence', Social Semiotics, vol. 18, no. 3, 2008, pp. 337, 348. On 'enfolding', see Giles Deleuze, The Fold: Leibniz and the Baroque, University of Minnesota Press, Minneapolis, 1992. Rose, Inventing Our Selves, pp. 188-93. Mitchell Dean, Governmentality: Power and Rule in Modern Society, Sage, London, 1999.

107 Anthony Giddens, A Modernity and Self-Identity: Self and Society in the Late Modern Age, Polity, Oxford, 1991; Giddens, The Transformation of Intimacy; Rose, Inventing Our Selves.

108 Rose, Inventing Our Selves.

109 Russell Keat and Nicholas Abercrombie (eds), Enterprise Culture, Routledge, London, 1991.

R. Selden, 'The Rhetoric of Enterprise' in Keat and Abercrombie.

110 Keat, p. 11.

111 Baer, p. 303. 